\title{
LOW-INCOME HOUSING AND SUSTAINABILITY OF THE SLUM IMPROVEMENT PROGRAM IN BANGLADESH
}

\author{
Mohammed Mahbubur Rahman*
}

\begin{abstract}
Slums providing housing to a good proportion of urban population in many developing countries have grown dramatically. Governments, mostly assisted by the international agencies, have achieved improved environments, tenure security, raised income and resources in many of these. Yet that could not eradicate the problems as benefits could not be sustained due to lack in institutional development, policy implementation, governance, participation, etc. Moreover, the urban poor's capability to bring affordable and sustainable solutions, which can be improved with assistance, was overlooked. This paper discusses the changed approach to the issues of low-income groups housing in the above context, and examine the same in the context of Bangladesh. It also evaluates the achievements and sustainability of the Slum Improvement Program therein.
\end{abstract}

Keywords: Capacity Building, Empowerment, Housing, Participation, Slums, Sustainability, Urban Poor

\section{INTRODUCTION}

The UNCHS' 1996 "global call” to ensure adequate shelter and sustainable human settlements for all has put the onus on the governments. Urban population in the developing world, to be doubled by 2030, will include huge growth in the number of slums, housing a sixth of humanity manifesting urbanization of poverty and inequality. Given their social, economic and political situations, most of the poor can manage only slum houses. According to the UNCHS (2005), the number of slum-dwellers will become 1.4 billion in 2020 . The Millennium Development Goals (MDGs) urged to improve the lives of only 100 million of them by then (UN, 2000). Yet, nations have succeeded little in reducing poverty, reaffirming the principles of governance and progress.

This paper draws an outline of sustainable housing from the ideas of Sustainable Development (SD), discusses housing of the low-income groups (LIGs), particularly in Bangladesh, and evaluates the Slum Improvement Program that has been on-going in last quarter of a century, assisted by the international funding. It draws from literature in order to form an understanding and set criteria for sustainable housing development, and then compare various components of the projects in Bangladesh in terms of their sustainability.

\section{SUSTAINABLE DEVELOPMENT AND URBAN HOUSING}

At the 1992 Rio Summit, the UNCED produced 'Agenda 21 ' - a Charter of 27 basic SD principles that added an institutional pillar to the environmental, economic and social pillars. It identified programs such as providing adequate shelter for all, improving human settlement, and promoting sustainable land-use, energy, transport and construction. Cities aspire to become sustainable by meeting basic requirements. Revolutionary implications of SD for urban planning and management sound wholesome to everybody (Greider, 1997). SD, bridging the gap between ecological concerns about the consequences of human actions and socio-economic concerns about development issues, advances social equity, expands effective organization, builds capacity, and validates more attention to environmental conservation and protection than with development (Roseland, 2000).

Though indicators of sustainability of community projects vary, some common indicators were: reliability of the system (availability of skills and expertise for regular functioning), human capital development (improve project understanding and community capacity for effective operation and management), development of institutional capacity (trainings and projects to improve the capacities of local bodies), inter agency collaboration, effective use of the system (planning and implementation), and replicability. Besides economic and physical objectives, SD needs to meet social, political, environmental and cultural ones, and basic human needs. Hence it should promote economic growth, maintain social inclusion, and minimize environmental impact.

* Mohammad Mahbubur Rahman, Dean, Faculty of Architecture, Kingdom University, Bahrain Email Correspondence: mmrahman417@gmail.com 
SD integrates community and quality that takes it beyond planning and policy domains (Stead and Stead, 1996). The post-industrial societies increased efforts to embrace sustainability through a sound and stable framework of social development, public participation, good governance and environmentally sustainable policies and practices (Kates, et. al., 2005; Budd et al., 2008). These addressed social and economic equity, participation, environmental quality, economic vitality, urban sprawl, and supportive planning activities and policies. Thus, a city should have equitable access to utilities, health services and economy, creativity to optimize human potential and integrated and compact communities, actively pursue social equity, and engage citizens (Parris and Kates, 2003; Kates, et. al., 2005).

'Agenda 21' laid down guidelines for sustainable urban development, asking the municipalities to mobilize broadbased, participatory and sustainable improvement. Housing, an important aspect of urban development, contributes to sustainability (Tosics, 2004). Forster-Kraus, et al. (2009) found social aspects of housing as important as the environmental and economic dimensions of sustainability. Thus the economic sector addressing the financial aspects of social justice, and accompanying the environmental sustainability, is an important element of it, while the environmental limits constrain economic growth. Yet the concept of sustainable housing with economic, social and environmental implications emerged later than the environmental approaches (Choguill, 1999).

Moore and Scott (2005) linked SD with the quality of life, well-being and liveability. Housing, an essential component in those, serves sustainability in several ways. MacLaren (1996) outlined related issues: economic vitality and diversity, community self-reliance, individual well-being, and satisfaction with basic human needs. The effects of the environmental impacts associated with housing may be worst for the LIGs (Huby, 1998), who has less choice, and may concentrate in areas of dereliction, with limited access to quality spaces and services. The poor face many constraints in making improvements, which deprives them from quality life, negatively impacting their physical and mental state.

\section{Poverty, Development and Housing}

Anand and Sen (2000) have extensively studied the reciprocal relationship between poverty and capability to expand social opportunity in markets, state policy and households (HHs). He based human well-being on development that expands people's freedom and capabilities through economic growth, increased income, technological progress or social reform. Thus SD policies should focus on building individual capabilities, and ensure freedom of people to achieve desirable life, more significantly of the poor.

That poverty is a threat linking environmental degradation with human development, downplayed the role of wealth (Roseland, 2000). Thus growth around macro-economic stabilization was a preferred strategy for the developing world in the early-1980s (Pugh, 2000). Promoted by the World Bank in the 1990s, development emphasized on broader urban issues and poverty alleviation through socioeconomic transformation, and sustained economic growth and modernization for a balanced urban development. These target improvement of living qualities, poverty reduction, job creation, production and environmental sustainability. Combining sustainability with its threat, development, is paralleled by calls to include the LIGs (Clark, 2001); it restores a broader socio-economic purpose of housing equity.

Significant social and economic changes are required for environmental improvements as technical solutions alone cannot protect progress. Hence the reformists suggested promoting sensitive human development to remain sustainable. Proper housing enhances the social, economic and environmental well-being, and transmits sustainability across generations (Ballet et al., 2003). The slum-dwellers lacking services and environmental security cannot participate fully in the community (Peattie, 1987). Recent attention to environment and Quality of Life shifted its role in improving living standards and sustainable human development (Anand and Sen, 2000).

Role of informal sector offering sustainable housing in the developing countries, as locale for socio-economic transformation, was recognised late. Pugh (2000) valued their social, cultural, economic, political and architectural implications. Gradual upgrading of such housing caters to the flexibility of their low and intermittent income and survival needs (Smets, 1999). Personal commitments and appropriate human bondage, generated in LIG housing through freedom and control over the process, can lead to poverty reduction. Good housing increases health and economic productivity too over long-term development transitions (Fogel, 1994).

Pugh (1997) found marks of self-help, HH economics, affordability and home sense in the roles of individuals and HHs, time and energy in home building, domestic chores, income generation (IG), physical improvements, human capital formation, and personal and community activities. As domestic, commercial and the public sectors interacted to bring overall socio-economic development of the LIGs, contribution of home economics, affordable housing, 
environmental improvement and human and labour development became important in SD. Recognition of rights, steady income growth, and development of social capital and empowerment of the LIGs can improve housing.

\section{Approaches to Slum Improvement}

Paying attention to the gross shortages and huge slums in the fast growing developing world cities in the 1950s, international agencies started providing advice and project assistance. As direct delivery failed to reach the LIGs, 'aided self-help' and 'site-and-services' followed in the 1970s. But their success was limited by poor economy and small scale; in situ upgrading and incremental building were ignored despite their sustainable qualities (Abbott, 2002). Turner (1976) phrased "freedom to build" or "housing is a verb" to support people's 'participation' in a 'process', and proceed according to capacity.

By then, viability of self-help housing was apparent; the 1976 Vancouver Habitat Conference endorsed a large-scale intervention. Despite having low impact, sites-and-services schemes remained dominant due to funds and instant benefits (Rahman, 1999). Facing problems of recovery, remoteness, inaccessible employment, gentrification, institutional incapability, participation, eviction, corruption, etc., these projects failed to address the core issues, and precluded employment generation and growth of affordable housing. As structural reform was needed to ensure sustainability and replicability, the World Bank in the 1980s was replacing projects with comprehensive policies and programs. Hence the international agencies withdrew from direct building, and financial institutions were set to reach target and increase recovery. The municipalities and the NGOs started to assist the LIG to mobilize and develop organizations, instil selfhelp skills, and increase access to credit (Rahman, 1999).

Government's role as housing provider was not suitable for the developing countries (Abbot, 2002). The idea of the private market providing low-income housing, reducing the state's involvement, was accepted in the late 1980s. Agencies started to encourage supporting enhancement of economic efficiency and social effectiveness, through deregulation and institutional development of the land and housing markets (Kimm, 1987). By the 1990s, focus shifted to holistic development to take account of such issues. As more reforms were needed to sustain benefits, strategies were set to develop finance further, reduce backlogs, increase basic infrastructure, reform land management and policy to accelerate housing supply, provide targeted subsidies, and set institutions (Pugh, 2000).
The World Bank (1993) proposed the enablement of private markets for increasing housing production to meet the 'requirements of all by 2000', echoed by the UNCHS's target of 'adequate shelter and sustainable human settlements'. While the policy and enablement framework searched for social-relevance and sustainability, state facilitated participation and partnership emerged as a mode. Many governments reduced their 'providers' role, and replaced numbered target with building capacity (Tipple, 1994), through private sector participation. Such supports increase production, achieve adequate shelter and SD (UNCHS, 2005), and enhance economic efficiency, social effectiveness, and capability to solve own housing problems. The next section presents typical examples of slum improvement from Nairobi and Kolkata.

\section{Slum Improvement Examples}

The World Bank funded two large initiatives for upgrading Kenyan slums during 1978-91. Another such project funded by Germany during 1992-99 was resisted by absentee landlords and residents. Since the 1990s, several NGOs undertook smaller upgrading projects. The government in 2002 established legislation and finance instruments to upgrade slums. It disburses funds for slum upgrading, lowcost housing and infrastructure through the Slum Upgrading Department.

The UNCHS-launched Kenya Slum Upgrading Project in 2002 in order to secure tenure, improve housing standards and the physical and social infrastructure, was delayed by absentee landlords through court case. Construction of several high-rise buildings in East Soweto started in 2012. The 'Kibera Integrated Water, Sanitation and Waste Management Project', completed in 2010, is considered as the first successful infrastructure and services upgrade initiative (UNCHS, 2014). Kibera, Kenya's largest and one of the world's most notorious informal settlements, is also the most unsanitary and dense slum in Africa where nearly 300,000 people live on just 256 ha of public land. The living conditions in Kibera, caused by government indifference, remained unchanged for half a century. The Slum Upgrading Project improved basic urban services, e.g. road access, sanitation, and water supply, managed by local groups registered as community-based organizations (CBO) formed by consensus.

Lüthi (2016) identified lack of involvement of slum-dwellers at the planning stages, political interference by landlords, lack of coordination, high overhead cost, and inadequate experience of the municipalities as the challenges such interventions faced. There are, however, lessons to be learnt 
too. Slum improvements should allow community participation in planning, implementation, monitoring and management, through consultation, representation, and negotiating cost-sharing. Officials and staff lacking knowledge and skills to implement such projects require training. The slum-dwellers benefit when resources are spent to upgrade water, sanitation and transport services before tackling complex and political issues like resettlement or tenure security. Ensuring irregular communication and stakeholders' sensitization is essential to a process avoiding disruptions by interest groups.

In Kolkata, the 1950s Slum Clearance projects followed by the Slum Redevelopment created resentment among the slum-dwellers. From the early 1970s the government took more humane approach through a model of providing physical infrastructures like latrines, water supply, drainage, paved roads, street lighting, and garbage bins to 2 million slumdwellers. Haldar, et al., (2016) identified its two limitations: no provision for maintenance, and ignoring the healthcare facilities and community development through income generation, primary education, or social amenities that affected a comprehensive development. Hence, DFID funded the Calcutta Slum Improvement Project (CSIP) to improve slums by addressing the needs and aspirations of the slumdwellers. It had physical infrastructures, healthcare services, community development, and training and evaluation components. Although CSIP benefited a large number of poor, little linkage was built with municipalities, and operations and maintenance of community assets remained a concern. Participation in project planning and implementation was on paper only as political leaders with own motives were sitting in committees formed to take over the project.

The next initiative, was an integrated approach for developing and providing the poor access to physical and social facilities through their participation in all stages. Besides an equitable access to services, capacity building and improved financial management were to ensure self-sufficiency for the municipalities to inherit the project. The latest intervention, the National Urban Renewal Mission, provided the local bodies opportunities and access to funds to carry out projects incorporated in the Draft Development Plan (DDP) prepared in KUSP. Haldar et al. (2016) identified positive aspects in it financial incentives making municipalities competitive regarding efficiency, and preparation of DDP, pre-required for funds.

However, the participatory components could be better implemented by institutionalizing the Committee(s) and making those parts of management teams, which could provide basic services to the urban poor. Also, the NGOs could catalyze the proposed development (Halder, et al., 2016). Participation of the slum-dwellers alone would not sustain the project or enable the local bodies, given the budget constraints and the needs of the poor. But according to Halder, et al., (2016), they should be guided and the projects should be vetted by the experts to make those feasible. The participatory public expenditure management used began with budget formulation with citizens' participation, and ended with performance monitoring referring to the funds spent.

\section{Sustainability Components}

The above shows participation of communities in decisionmaking, project planning, design and implementation, managing projects, resources and infrastructure, and identifying need and setting priority, empowerment and capacity building as some of the indicators of project sustainability. A major MDG Strategy for SD is to make development projects effective by using community empowerment through participatory decision-making (Narayan, and Shah, 2000). LIG settlements can be improved by vesting resources and decision-making to the dwellers which can develop, manage and sustain resource (Patrick and Scott 2011; Rondinelli, 2006) and adopt transparent and accountable ways for good governance.

The international bodies support participation by integrating the informal sector in decision-making, shifting focus from centralized to community-based development; the Recife Declaration too stressed the importance of this. The UN (2005) endorsed a bottom-up approach, local capacity building, and institutional strengthening to alleviate poverty. The 1976 Habitat Conference suggested that stakeholders' representatives should identify and transform priorities into action plans. The 1992 Brown Agenda for SD also called for participatory environmental improvement focussed on community participation, partnership, accountability, etc. Agyeman, et al., (1996) advised to take a concerted local level action to implement that.

Identifying lack of relevant institutions and participatory capacities, municipalities were urged to mobilise community involvement in accountable planning and developments (Roseland, 2000). That the CBOs can facilitate community's participation and access to policy and collective decisionmaking in authorities (Watt et al., 2000; Clark et al., 2007), and mediate between empowerment and changes, has academic support (Huchzermeyer, 1999). Sara and Katz (1997) established participatory approaches as means to improve community ownership needed for SD. Mansuri and Rao (2003) found that community engagements lead to 
program sustainability. Drakakis-Smith (1981) observed that involvement in project design and implementation brings commitment and community connectedness.

Participation eliminates control over development activities by the elite and politicians (Patrick and Scott, 2011). It enhances interactions, social relations, control and confidence by fostering community welfare, healthcare and women skill (Rovai, 2002). Participation can be used to generate action plans, partnership and self-help, and define stakeholders' responsibilities. It is also a cost effective and sustainable means that can be used to identify and address community's concern (Nelson and Prilleltensky, 2005). Participation encourages cooperation for community development. The Sri Lanka Million Houses Program is an example where the community and the city jointly took decisions and defined actions. However, despite the support to community participation, it was not appreciated universally earlier (Abbot, 2002).

Participation, training and advocacy lead to empowerment and capacity building linked to sustainability (Fetterman, 2007). Empowerment provides people scope to participate in a capacity building process, enables them to transform choices to favourable outcomes (Alsop and Heinsohn 2005), and improve the quality of lives (Sidorenko, 2006). Several authors (Bennet, 2002; Bebbington, et al. 2006; Saegaert, 2006) treated empowerment as a tool to gain expertise, selfconfidence and control over local developments, enhance community capacities and assets to an extent of influencing decisions by local bodies and policy makers, and in bringing inclusion to overcome the livelihood barriers.

Similarly, Clark, et al., (2007) identified importance of empowerment in development policies. Laverack (2006) and Zimmerman (2000) identified participation, capability and accountability as interlinked elements of empowerment. Sustainability also depends on ability to deliver services by government bodies and groups (Chavis, 2001). Such participatory community-based initiatives will help citizens to improve their capabilities for collective action, leading to significant development outcomes like access to basic necessities and improved quality of life, and increasing equality (Gutberlet, 2009). Capacity-building increases community abilities to define, asses and address the issues related to its members (Laverack, 2006).

With capacity built, communities can deploy their resources and skills in order to address local problems, in addition to utilising technical know-how of the development agencies. These include efficiency and entrepreneurship of private enterprises, mediation between the HHs and agencies by the
CBOs providing management expertise, and self-help experience and local know-how of the participants (Pugh, 2000). The problem of exploiting environmental improvements can be resolved by a participatory and transparent management by assigning defined responsibilities.

\section{URBAN LOW-INCOME HOUSING IN BANGLADESH}

Urbanization in Bangladesh has been causing environmental deterioration by outpacing the housing services, infrastructure and job provisions, and making lives difficult for the LIGs. The 2011 census shows urban population in Bangladesh to be 42.73 million (28.4\% of total); there will be another 70 million added to that during this century. Dhaka, the capital city with 16 million people and tenfold growth in last 3 decades, suffers the most (Streatfield and Karar, 2008). 55\% of about 600,000 people added annually to it are destitute migrants (Lall, 2006). Three-quarters of increased population in Dhaka end up in the slums (Streatfield and Karar, 2008). The current rate of annual growth of the six metropolitan areas is $3.5 \%$; up to $55 \%$ live in the slums and squatter settlements in those cities (Rahman, 2001). Slums housed $37.4 \%$ of Dhaka's population in 2003 (Le Blanc and Buckley, 2006). These feature poverty, high density, lack of infrastructure and utilities, illiteracy, crime, environmental and psychological degradation, etc. (IDSS, et al., 1996; UNCHS, 2003). These grow on waste dumps, open drains and sewers, low land, embankments, and along rail lines, $65 \%$ of which get inundated during rain (UNCHS, 2003). Most slum-dwellers are employed in the informal sector, featured by low wages, long working hours and insecurity (Le Blanc, et al., 2006). Only 19\% of HHs earning less than US\$ 1.5 a day go to modern clinics (Rashid and Hussain, 2006); $9 \%$ of the poorest quintile uses a sewerage system; only $2.5 \%$ of them live within $100 \mathrm{~m}$ of a toilet; $70 \%$ of poor do not have access to piped water and $90 \%$ to sewerage (Lall, 2006). Less than $20 \%$ of HHs is satisfied with the basic services; among the poor in Dhaka less than 5\% was satisfied (Rashid and Hussain, 2006). Most utility agencies do not serve the slums; these manage low quality limited services from a mix of government, NGOs and individual sources, often illegally.

\section{Public Housing}

Policies and institutions in Bangladesh failed to facilitate the LIG an easy access to land and shelter. Cost and scarcity of resources, particularly land, and lack of access to finance and power marginalized them in the housing market. Planned development and land subdivision by government agencies and real-estate developers were availed by the higher echelon. As the government failed to address shelter and socio- 
economic needs of the poor in a large scale, and assist others to supplement its efforts, many depended on the informal sector. This sector produced $85 \%$ of 1 million dwellings in Dhaka (Islam and Shafi, 2008). Rahman, (2010) identified gaps between the government policies and programs due to a lack in its commitment and dependence on external funds. Investment was left to the profit-driven private sector as the government did not consider housing's developmental role.

Despite the government admitting that the programs were ineffective, the subsidized sites-and-services plots turned posh residential areas and staff housing remain dominant public housing type. Concentrated mainly in Dhaka where around 100,000 public sector units serve less than $10 \%$ of the population (Islam and Shafi, 2008), these are inadequate compared to the huge requirement. Annually over 83,000 housing units were needed in Dhaka in the mid-1990s, which was a third of the total urban area requirement. Dhaka Structure Plan 1997 estimated a requirement of 2.34 million new housing units for a period till 2025 in the city; half of those were for the LIG. The UNCHS updated it to 120,000 units in Dhaka and 400,000 units in other urban areas in 2003.

The government readmitted its inability to meet the housing demand with meagre resources in the 1990-95 Plan. The 1978-80 Two Year Plan mentioned that the service and finance agencies catered a lot for the rich, shunning attention and investment for the others. The next Plan (1980-85) admitted that conventional approach couldn't solve the huge problems. Selectivity ought to be practiced by using own resources to ease the shortage, increase the stock by providing plots, utilities and easy-term finance, and reduce the residential entitlement to optimize resource-usage. The 1985-90 Plan opined that the policy of developing posh enclaves amidst the slums was to be reversed by catering to the others needs too. Hence the Plan advocated a gradual intervention by the government to plan and develop land, infrastructures and services, arrange finance, and stimulate others' participation. The next Plan (1995-2000) aimed to improve the life quality of the people and their working environment by providing adequate infrastructures, loans and other services. Thus the Slum Improvement Program introduced several consecutive projects that aimed at empowerment and capacity building in the urban slums through participation, and social, economic and environmental development.

\section{Poverty Situation}

TW (2013) noted that of its 150 million people, Bangladesh had reduced the number living in poverty from 63 million in 2000 to 46 million in 2010. Poverty reduction plans in Bangladesh have traditionally focused on the rural areas though a substantial number of poor live in its urban areas. There are about 9.4 million urban poor in Bangladesh (21.3\% of all urban) (BBS, 2010). Poverty is linked to landlessness and limited opportunities for education and employment, especially for women and girls. The housing situation of urban poor, or slum-dwellers, lacking basic services, is appalling. Consequently they suffer from crowding, insecurity, and criminal activities. The low skilled workers have little scope of increasing income, access education or health services making accumulation of human capital difficult.

BBS, (2010) shows that poverty in Bangladesh was declining at a rate of $2.47 \%$ annually since 1991 ; the target of halving the percentage of poor was achieved by 2012. It met several targets of the MDGs two years ahead (TW, 2013), including those of reducing poverty gap and attaining gender parity in education. Yet many poor HHs cannot afford proper meals, and mothers and children mostly suffer from malnutrition. Unaffordable health cost further aggravates the problem, and affects education and income generation. Employment generation especially for women, school completion, adult literacy rates, etc. are areas requiring attention now to sustain the overall improvement in the living conditions.

\section{Public Housing and Slums}

States seldom tolerate illegal and irregular housing (Abbott, 2002), and resort to their destruction; the Bangladesh government is no exception. At least 135 notable cases of eviction occurred in Dhaka in quarter of a century since 1975 (Ahmed, 2007), which still prevails. Eviction ignores the socio-economic problems causing the slums, and redistribute poverty to less valuable area (Rahman, 2001). Instead upgrading of the slums was suggested in various government documents, e.g. the 1993 National Housing Policy. Few shelter schemes by the NGOs showed the poor's capability to improve housing that increases productivity and income; these are affected by lack of land ownership (Rahman, 1999).

In the 1990s, the government with the support of international agencies initiated various slum improvement projects implemented mainly by the Local Government Engineering Department (LGED), some municipalities, government agencies and NGOs. These included IG, infrastructure improvements, skill, hygiene and nutrition training, and 
community mobilization (Rahman, 1999). The projects alleviated the unhygienic and unsanitary conditions of some slums by constructing drains and sewage lines, footpaths, latrines, garbage bins, tube wells, flood protection, and street lighting. However, Chowdhury and Amin (2006) found that piecemeal implementation barring proper assessment, staffing and coordination contribute little and affect the environment adversely.

Most of the early public housing programs in Bangladesh failed to reach number targets (Rahman, 2010); despite having a huge LIG, these mainly served the privileged ones. Some changes in government approach only began as directed by the international financing agencies. These [slum improvement] projects came out of the notion of 'shelter' as an 'end product'. The government gradually shifted from the 'provider' role, and took up social, economic, environmental and institutional development projects for the urban poor. These are building capacity of the LIG to make and sustain housing improvements.

\section{SLUM IMPROVEMENT PROGRAM IN BANGLADESH}

The 'First Urban Project' in Bangladesh, based on a UNICEFfunded study of poor in four large cities, was implemented by the Department of Social Services during 1982-1985. It aimed to provide IG loans and healthcare to women, establish day-care centres, and build sanitation infrastructure in few slums. As progress was slow due to lack of experience in delivering urban services, the LGED was asked to coordinate the projects towards the end, and strengthen interagency collaboration both at local and national levels. Since then, it has implemented a number of slum improvement projects covering various components (Table 01).

These experiences led to the Slum Improvement Project (SIP), providing basic services and socio-economic facilities by combining community development and health education with physical improvements and income generation. It accepted that physical improvement could only be sustained by human development. The SIP, started as a pilot project in five towns with UNICEF-funding, covered $7100 \mathrm{HHs}$ in 16 towns in the first phase (1985-88). The project components particularly targeted the women. It established tube-wells, latrines, footpath, drains, garbage bins, street lights, satellite schools, and skill training. The second phase (1988-93) modified the plan to expand coverage $(15,000$ HHs in 25 towns), and be more efficient. It linked basic services to capacity building when extended further in 1996 , and later revised into Urban Basic Service Delivery (UBSD) project.

Country cooperation frameworks of UN agencies in the 1990 s set the priorities and the objectives of the Government - to alleviate poverty by raising the income level and living conditions, and maximize impact of human development through environmental management,

Table-1: Summary of Slum Improvement Projects in Bangladesh, 1985-2015.

\begin{tabular}{|c|c|c|c|c|c|c|c|c|}
\hline $\begin{array}{l}\text { S. } \\
\text { No. }\end{array}$ & Name of Project & $\begin{array}{l}\text { Funding } \\
\text { Agency }\end{array}$ & $\begin{array}{l}\text { Project } \\
\text { Duration }\end{array}$ & $\begin{array}{l}\text { Slum Improvement } \\
\text { Cost (US\$) }\end{array}$ & $\begin{array}{l}\text { No. of } \\
\text { Municipalities }\end{array}$ & $\begin{array}{l}\text { No. of City } \\
\text { Corps. }\end{array}$ & $\begin{array}{l}\text { No. of } \\
\text { Slums }\end{array}$ & $\begin{array}{l}\text { No. of } \\
\text { Families }\end{array}$ \\
\hline 1 & Slum Impovement Project (SIP & UNICEF & $1985-88$ & 5.9 & 5 & & 25 & 2000 \\
\hline 2 & $\begin{array}{l}\text { Slum Impovement Project-II } \\
\text { Secondary Town Infrastructure }\end{array}$ & UNICEF & $1988-96$ & 243.4 & 21 & 4 & 200 & 43000 \\
\hline 3 & $\begin{array}{l}\text { Developemtn Project-I (STIDP) } \\
\text { Secondary Town Infrastructure }\end{array}$ & $\mathrm{ADB}$ & $1992-97$ & 37.08 & 10 & & 43 & 225 \\
\hline 4 & $\begin{array}{l}\text { Development Project-II } \\
\text { Secondary Towns Integrated Food }\end{array}$ & $\mathrm{ADB}$ & 1996-01 & 77.2 & 22 & & 100 & 10000 \\
\hline 5 & Protection Project-II (STIFPP) & $\mathrm{ADB}$ & $1992-98$ & 36.47 & 5 & 1 & 49 & 8356 \\
\hline 6 & Urban Basic Service Delivery Project & UNICEF & $1996-01$ & 342 & 0 & 4 & & 165000 \\
\hline 7 & $\begin{array}{l}\text { Community Empowrment for Urban } \\
\text { Poverty Alleviation }\end{array}$ & UNDP & 1996-01 & 603 & 0 & 4 & & 120000 \\
\hline 8 & $\begin{array}{l}\text { Municipal Services Project } \\
\text { (Slum Component) }\end{array}$ & WB & $1995-00$ & & 14 & 2 & & 0 \\
\hline 9 & $\begin{array}{l}\text { Urban Povery Reduction Project } \\
\text { Local Partnershipsfor Urban Poverty }\end{array}$ & $\begin{array}{l}\text { ADB } \\
\text { UNCHS/ }\end{array}$ & 1998-02 & 0 & 0 & 1 & 0 & 0 \\
\hline 10 & Alleviation Project (LPUPAP) & UNDP & $2000-07$ & & 7 & 4 & 0 & 0 \\
\hline 11 & $\begin{array}{l}\text { Urba Partnership for Poverty } \\
\text { Reduction (UPPR) }\end{array}$ & $\begin{array}{l}\text { UNDP/ } \\
\text { UNCHS }\end{array}$ & 2008-15 & 120 million & 23 & 0 & 0 & 0 \\
\hline
\end{tabular}


employment generation, women advancement and good governance. The UNDP supported the Local Partnerships for Urban Poverty Alleviation (LPUPA) project during 19992004. It aimed at implementing community-based activities to upgrade living, economic and social conditions of the poor in 12 towns by enabling decision-making, in addition to capacity building of local government and officials.

While UBSD addressed the service needs, LPUPA assisted the communities to alleviate poverty through partnership, women empowerment, and participation. As UNICEF-funded Support for Basic Services to Urban Areas (SBSUA) project was similar, the second phases of LPUPA and SBSUA were merged to run till June, 2007. The LGED, implemented the program with technical assistance from the UNCHS, and handled the Community Development Fund and Poverty Alleviation Fund. Phase I of it included supply of basic facilities, poverty alleviation, empowerment and capacity building; Phase II added saving and credit, education and hygiene to sustain the project benefits. These were delivered through Community Development Committees (CDCs), which organized the credit groups to handle micro-credit.

In 2008, the Urban Partnerships for Poverty Reduction (UPPR) project initiated in 23 towns was funded by UNDP in partnership with the Government of Bangladesh and UNCHS. This aimed to improve the livelihoods and living conditions of a third ( 3 million) of all urban poor, and eliminate their poverty by 2015 . Activities included improving the settlements physically, enhancing socio-economic scopes, and developing savings and credit groups (SCGs). UPPR also aimed at developing strategies to enable the poor defeat poverty and be socially integrated through capacity building and participation, and empower communities to make decisions, implement solutions, and manage development.

The success of these projects hinged on strategies regarding community organization, inter-agency collaboration, capacity of municipalities to deal with the poor, social and physical network, accessibility, women and children, and rights. A community-based approach was adopted to facilitate primary education, health education, etc. The environmental upgrading generally improved the areas; increased income made more investment available to improve living conditions. The UNDP et al. (2007) found the project slums improving in terms of family headship, education, occupation, health, housing, etc.

\section{Governance}

In the slum improvement projects, about 20 mainly women, form Primary Groups (PGs), which in turn form the CDCs, representing up to $300 \mathrm{HHs}$. Several CDCs form Cluster Committees to share experiences and lessons through networks. These clusters are organized in Federations to provide training, assist in setting partnerships and linkages, and mobilize resources. These also oversee the CDCs and SCGs, advocate pro-poor planning, and monitor resource distribution. Duality in these committees with the Project Implementation Committees (PICs) in SIP created problems. The elected Commissioners represented the community in municipal activities. But with no executive power in the committees, they became non-committed. This often hindered the community involvement in the economic and environmental activities.

Ghafur (2000) found that the SIP-beneficiaries critical of municipality's role were oblivious of participation. The isolation and deprivation that result from excluding $\mathrm{HHs}$ from the decision-making, made them non-enthusistic to appropriate available development opportunities. This inhibited their 'participation'. Some of these difficulties were overcome later through participatory decision making. Menon (1998) termed the SIP as a community based effort; yet these lacked much participation by the beneficiaries. Decisions were influenced by some HHs and committee members. For example, site characteristics or residents' opinion and needs were not considered in laying out and locating infrastructure. The elected members and local leaders were to assist the CDCs in developing infrastructure, and linking the LIG to the mainstream development. However, financial motivation of local politicians made resource appropriation difficult (Ghafur, 2000).

'Participatory Identification of the Poor' method was used in the UPPR to avoid their disenfranchisement with the authority adopting standard criteria. Each community discusses and agrees upon various criteriaÊto identify needs and categorize the HHs. Adherence to guidelines, monitored by the government and funding agencies, achieved some accountability. The members had nominal voice as the Chairman with executive power was inclined to safeguard the authority's interest. The formal manner in which meetings were conducted disadvantaged the less literate members.

\section{Capacity Building and Empowerment}

Capacity building initiatives in the projects included training of representatives, government staff and community leaders (field exposure, group discussion, construction training and guidance, finance and contract literacy, etc.). SODEV (1999) identified inadequate support to staff, and rigid criteria for implementation, infrastructure standards and selection procedure as problems in the SIP. Some agencies had no experience of delivering grassroots services. But defined roles and responsibilities, experience of working together, and inter-agency collaboration were well set by 1999 when 
the LPUPA was started. The UPPR tried to overcome these by building some capacity.

The Community Organizers (COs) brought about community participation and organization; but the authority ignored their performance and commitment (SODEV, 1999). Moreover, slum hierarchy and group dynamics often prevented them from discerning community's needs and wishes, and succumbing to the leaders' influence. Prejudices and lack of social skills made the COs initially unable to communicate with the target group. This was overcome by going through the pilot projects learning to engage the communities and enlist their trust (Rahman, 1999). Their capacity to organize communities, supervise activities, disseminate information, make and implement plan, and set target and objectives was also increased through training.

By getting involved in the planning and execution, the community members developed skills transferable to employment. But the SIP ignored HHs' ability to identify their own problems; this was gradually incorporated by encouraging greater participation, for example in the CDCs that identified needs and prepared Community Action Plans (CAPs) on improving living conditions. $615 \mathrm{CDCs}, 8,000$ primary groups and 145,000 families implemented various CAPs components (2007). Each CDC also received support to prepare and manage construction contracts. Such exercises help community members realize relevant capacity and the right, and create leadership scope.

The Community Health Workers (CHWs), who played a crucial role in providing health awareness and education, required more training, resources and incentives to be effective (SODEV, 1999). Health awareness grew considerably, evident in reduced child mortality (UPPR, 2015). However, the management capability at various levels was not coping with the rate of program expansion. Maintenance plan, maintenance fund and skilled manpower would increase sustainability. Apprenticeship gave hope and reduced criminal propensity among the unemployed youth. In UPPR, 65,234 beneficiaries received skill development training till June 2014 (UPPR, 2015); $85 \%$ of those found regular jobs within 6 months. Construction related jobs and within-slums employments as community organizer, caretaker, etc. were also created.

95\% members in committees and credit groups were women, who were successful more often as leaders (holding $91 \%$ of positions) (UPPR, 2015). Empowering the women having voice in decision-making raised their social status, and reduced abuse. They could construct basic amenities, participate in economic activities, enforce health habits, and contribute in awareness building, literacy, resource management, etc. Later projects recognized that with contributions to incomes and child rearing, women were the socio-economic change agents.

\section{Finance}

The projects recognized the role of finance as the poor's lack of access to banks made accumulation of savings for generating income or improving living difficult. Hence the communities were enabled to establish SCGs linked to the PGs to mobilize resources, generate income, and increase assets. Unlike in micro-credit schemes, SCGs in UPPR use their own savings, and finance microenterprise activities. Small business grants creating employment opportunities led to confidence building. A share of the profits from the schemes was used to cover costs for community empowerment.

However, some schemes were ill-managed, meetings and record keeping were irregular, and most members were financially illiterate. Though small loans provided initial impetus, the SIP borrowers were not helped after having established creditability and improving financial situation. Home improvement was not possible with small loans, and waiting time was long. Moreover, committee members and leaders could influence loan sanctioning. Hence many slumdwellers did not take loans which affected potential entrepreneurs. However, credit program had $90 \%$ recovery record. Of over 395,000 members in UPPR program alone, $30 \%$ got small enterprise grants from US\$ $7.6 \mathrm{~m}$ accumulated in the fund (UPPR, 2015).

\section{Health and Education}

Identified by Menon (1998) as one area of success of the SIP that owed to education and awareness. The CHWs linked to the National Health Program were facilitating the planning, implementation and monitoring of child immunization, Vitamin distribution, control of water-borne diseases, family planning, breast feeding and growth monitoring. Components like distributing various supplements were targeted at women, girls and children as malnutrition is tied to low social status of women (TW, 2013). Some projects provided services like training, workshops and counseling on nutrition, breastfeeding and hygiene practices. Subsidized drinking water and sanitary latrines were expected to reduce work absenteeism, and enhance productivity and income (SODEV, 1999). The UPPR ran a scheme to assist food producing HHs, and arrange for the training and skill sharing through the CDCs. These helped them to adopt good practices and improve health and income.

Schooling of children, especially girls, is threatened by the absence of social safety. Other than poverty, girls are affected 
by early marriages. Although primary education is free in Bangladesh, many cannot afford additional expenses, and dropout. This results into poor human capitalÊformation and inability to break the poverty cycle. UPPR provided grants to 111,146 Êvulnerable pupils to complete primary schooling (UPPR, 2015). It also undertook initiatives like advocacy, youth development, and early marriage, early pregnancy, dowry, and gender violence advocacy.

\section{Physical Improvements}

Security of tenure plays a crucial role in poverty reduction by integrating the urban poor in socio-economic activities. It removes fear of eviction and helped poor families to exploit opportunities, for example using land titles as loan collateral, which also serve as a base to pursue rights to health services, education, social well-being, property, and for improving housing conditions (Peattie, 1987). UPPR used Settlement Land Mapping (SLM) where slum-dwellers mark vacant land. Then trained COs assessed and categorized the poverty level of the settlements by using 16 indicators. This can be used to select type of assistance, and plan slum rehabilitation. UPPR got the SLMs endorsed by the local government institutions to integrate those in the Town Plans, and include the slum-dwellers in government programs. It also developed alternative to eviction to improve tenure security. In Gopalganj, 24 poor families were living as informal tenants for over 30 years on a waterlogged polluted area with no toilets and water supply. Assisted by the UPPR, they negotiated with the landlord to rearrange layout on the same land and improve the settlement in exchange for a 20 years lease.

Targets of building safe and affordable utilities for improving the environment and hygiene situation were overwhelmingly met. Against a target of 173,119 latrines, it had set up 186,401 by mid-2014. The UPPR targeted to supply water to 195,433 HHs, and till June 2014, it had achieved $126 \%$ of it. Against a target of serving 400,225 HHs with drains and footpaths, it reached 470,107 HHs (UPPR, 2015). Almost all the tube wells in the UPPR-slums were made arsenic free. Paved ways and drains were built too UPPR ran a Settlement Improvement Fund (SIF) to support physical improvements. The CDCs contracted out works identified in the CAPs, like drains and footpaths extension, and construction of latrines and reservoirs. Such contracts stimulated local economies by supporting manufacturers and businesses, and achieved value for money; it saved US\$ $4.7 \mathrm{~m}$ up to 2012 through project costs $15.5 \%$ below-standard-government-rates. A sense of ownership over the output results in communities ensuring construction and maintenance quality; trained beneficiaries could maintain all the facilities themselves. Moreover, infrastructure development and service delivery identified by the communities themselves met the needs and priorities, especially of the vulnerable groups (Figures 1 and 2).

Through the Socio-Economic Fund (SEF), UPPR supported activities that improve the conditions of urban poor, like apprenticeships and grants for small business, to keep girls in school, and for food production. The project also facilitated communities to access support to housing and housing finance. It has helped them in two cities to establish a revolving Housing Development Fund (HDF) that allowed the poor to pool their savings to be used for various housing development activities.

\section{DISCUSSION}

Bangladesh, instead of waiting for needed resources and technology, should promote sensitive and efficient human development, taking collective responses and social responsibility through poverty reduction, job creation, environmental sustainability, economic enhancement, and improved living. It should build individual capabilities to

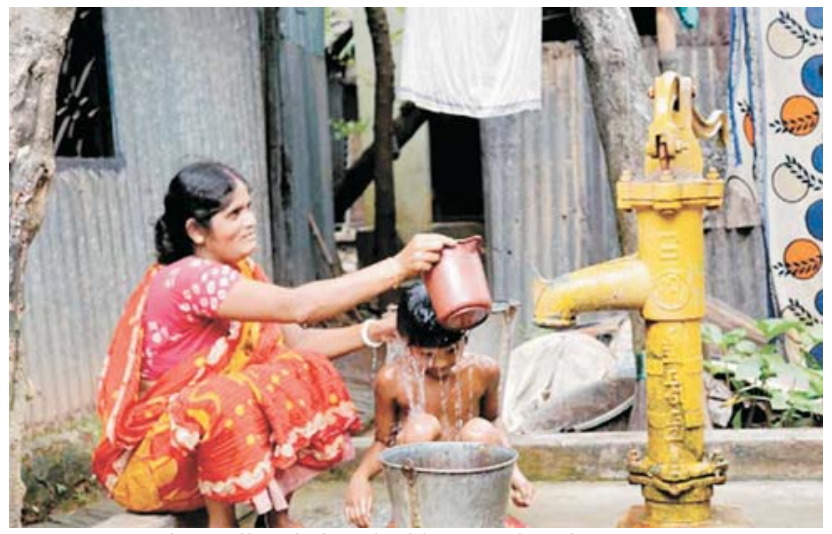

Figure-1: Tube Well and clean bathing spot ina slum. Source: Architect Ahsan Feroze

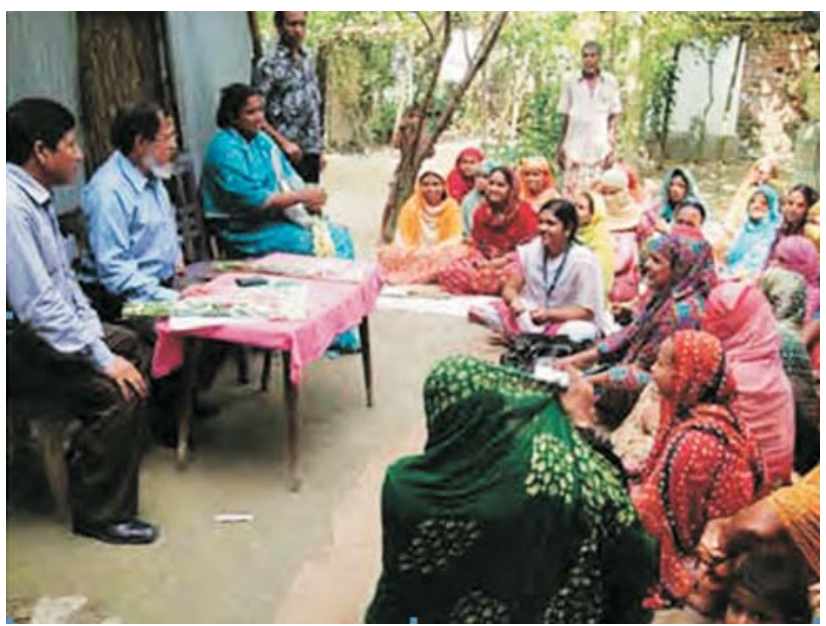

Figure-2: Project Officials meeting Slum Representatives in Chandpur Source: Architect Ahsan Feroze 
convert resources into desirable outcome that can be transmitted across generations. Amidst reconstruction priorities in war-torn country after independence in 1971, short-term strategies like slum improvement, sites-and-services, and minimum shelters to house the LIGs were included in the National Plans. Though unsustainable, ready houses for select groups remained as a popular public housing component (Rahman, 2010). Improving the slum environment started in the late-1980s.

The IG skill training and loans in the program encouraged the recipients to become home-based entrepreneurs. This was sustained by the multiplier effect on the socio-economic and human resource situation (affordable housing, environmental improvement, and contribution to human and labour development, stable income growth, development of social capital, empowerment, etc.). The program utilized the expertise of agencies, and included stakeholders aimed at participation and capacity building, and strengthening local bodies.

Capital and capacity built in the projects (organizations, leadership, technical and managerial ability, various awareness, participatory experience, savings etc.) initiated a social change by advancing socio-economic equity, and exploiting the capacity for transition using own resources. The projects limitedly achieved environmental improvements with equitable access to utilities, health services, opportunities and skill development. These helped to promote economic growth, maintain social inclusion, and minimize environmental impact towards SD. These also met the sustainability criteria Silvius (2012) put: harmonizing social, environmental and economic interests, consuming income, transparency and accountability, and personal values and ethics.

Ghafur, (2000) apprehended that interventions in the slums would remain crucial as the communities could not instantly become self-sufficient, mobilize resources and acquire technical knowledge to design and implement different projects. Given the resource scarcity and lack of technical knowledge, dependence on external resources and technical assistance would continue. He advocated for the Poor's entitlement to state patronage to improve their housing and livelihood. But patronage kills capabilities of the LIG, forces dependence on external assistance, making housing unsustainable in the long run. However, with the introduction of participatory approaches the post-1999 projects increased the community's ability to make decisions.

Ghafur, (2000) refuted the assumption that the SIPbeneficiaries and their settlements were socio-economically homogenous, and adherence to the guidelines would ensure a good performance (Figure 3). Efforts to build staff capability, motivate and organize the beneficiaries, and convince the slum-owners were less effective as there was no time taken to analyse, assimilate, and apply the learning from the pilot projects. Also rigid procedure did not fit contextual peculiarities of randomly selected slums; some worse or larger ones were left out. Though each project continued adding components, none included the squatter settlements mainly on landownership ground.

Tenure security enhances the affordability of incremental upgrading fitting the circumstances of the poor. This increases housing supply, and reduces the government's burden. Grassroot participation empowering the community to upgrade the slums and own assets make a process accountable. Participatory decision-making, transparent management, and institutional and organizational capabilities could bring good governance. However, the program was not much successful on participation due to initial top-down approach.

The program did not utilize the target group's capabilities to make 'in-situ upgrading' and cost-effective solutions fitting their socio-economic needs, use self-help labour and other resources, or take advantage of increased income and

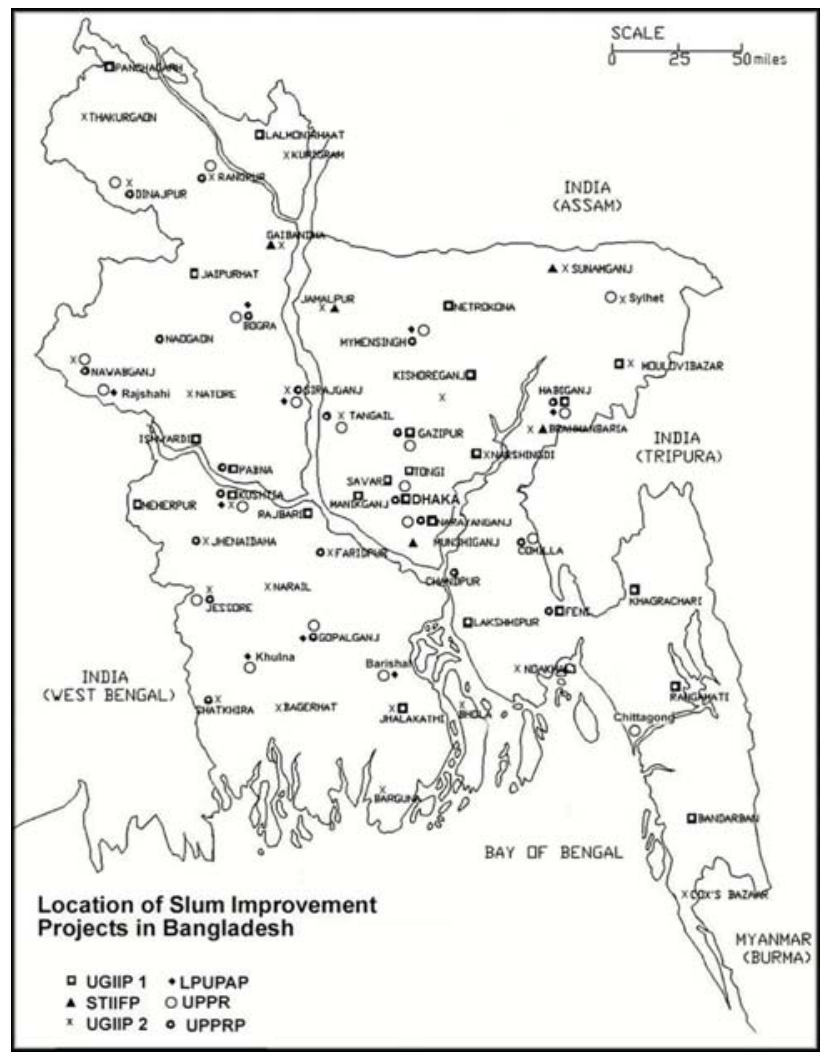

Figure-3: Map of Bangladesh showing the Location of the Slum Improvement Project. 
creditability. These neither enhanced freedom of individuals nor ensured their full participation, barring the development of environmentally sustainable practices. Except for enhancing women's role and status, these could not optimize human potential, use resources with low ecological impact, or pursue social equity. However, the later projects based on lessons of previous ones tried to overcome these.

Data suggest positive effects of awareness, capacity building, skill training, credit, women's emancipation, and environmental and physical improvements of the shelters; though more need to be done. These were available only from LGED or assigned reviewers. Continuation of a project often depended on performance measured by numerical targets. But the attributes like capacity building and empowerment are not measurable by numbers only. The evaluation should have focussed on the effects of the said achievements. Also changes in the conditions of the beneficiaries, for example their health and hygiene situations, were not measured over a period and compared with preproject situations.

The LGED undertakes infrastructure development in smaller towns. Despite a good rapport with the government and funding agencies, it has no jurisdiction over Dhaka city or mandate for slum improvement. Hence its domination often caused resentments among multiple authorities in Dhaka city (Rahman, 1999). LGED officials being mostly civil engineers preferred physical construction over the human aspects. Within the municipalities, only few reluctant personnel received capacity building training.

\section{CONCLUSION}

Against a migration-driven $2.2 \%$ per annum urbanization in Bangladesh, the slum population is growing at $7 \%$. Recent retarding rate owes to the expanding microcredit facilities in rural areas (Streatfield and Karar, 2008). This suggests that income generation and environmental upgrading is a feasible way to lift millions of slum-dwellers out of poverty, and provide them a decent place for living towards further prosperity. Hence a shift from providing direct shelter in the first two post-Independence decades to capacity building and empowerment through participation and income generation, and by enhancing sanitation, health and education etc. has been a positive move. Though primarily driven by the international agencies, the Slum Improvement Program can be sustained through participation of all stakeholders and empowerment of the slum-dwellers.

Participation of all in achieving sustainability is a necessary condition for development, among others by enhancing human capabilities with better health and education. This would reinforce the virtuous cycle of economic growth and human development, and allow institutions achieving a higher standard of living (Costantini and Monni 2008). While cities frequently adopt sustainability rhetoric, gaps exist in their operations (Jepson, 2007). Moving toward a sustainable society requires more than adjustments: create healthy, sustainable, pleasant and satisfying communities, make efficient use of urban space, multiply social capital, and mobilize citizens and their governments toward these ends. Sustainability, an attack on conventional thinking and practice, and a framework for urban future, provides an optimistic alternative. The global audience has pinned its hopes on this to solve the societal and environmental problems (Roseland, 2000). Though, policies for sustainable housing for the poor alone may not overcome the urban problems, without them no solution can be found.

\section{REFERENCES}

Abbott J., 2002, “An analysis of informal settlement upgrading and critique of existing methodological approaches". Habitat International, 26(3):303-315.

Agyeman, J., Bullard, M., Evans B., (eds.) 1996, Statement of Purpose, Local Environment, Vol. 1(1). Ahmed, K., 2007, "Urban poor housing in Bangladesh and Potential role of ACHR", ACHR, Bangkok.

Alsop, R., Heinsohn N., 2005, "Measuring Empowerment in Practice: Structuring Analysis and Framing Indicators", World Bank Policy Research Working Paper 3510, Washington DC.

Anand, S., Sen, A., 2000, "Human development and economic sustainability", World Development, Vol. 28(12):2029-2049.

Ballet, J., Dubois, J., Mahieu, F., 2003, Le développement socialement durable: Un moyen d'intégrer capacités et durabilité, Paper presented at: Third Conference on the Capability Approach, University of Pavia, Italy. 
Bangladesh Bureau of Statistics (BBS), 2010, "Household income and expenditure survey", Ministry of Planning, Dhaka. Bebbington, A., Guggenheim, S., Woolcock, M., 2006, "Concepts: Their contexts and their consequences", In: Bebbington, A., Guggenheim, S., Woolcock, M., Elizabeth, AO., (eds.) The search for empowerment: Social capital as idea and practice at the World Bank, Kumarian Press, 261-287.

Bennet L., 2002, Using empowerment and social inclusion for pro-poor growth: A theory of social change. Social Development Sector Strategy, World Bank, Washington DC.

Budd, W., Lovrich, N., Pierce, J., Chamberlain, B., 2008. Cultural sources of variations in US urban sustainability attributes, 257-267.

Chavis, D., 2001. "The paradoxes and promise of community coalitions", American Journal of Community Psychology, 29 (2), 309-320.

Choguill, C., 1999, "Sustainable human settlements Some second thoughts", In: Foo Af, and Yuen, B., (eds.) Sustainable Cities in the 21st century, The National University of Singapore, Singapore.

Chowdhury, F., Amin, ATMN., 2006, "Environmental assessment in slum improvement programs: Some evidence from a study on infrastructure projects in Dhaka slums", Environment Impact Assessment Review, 26(6), 530-552 Clark, M., 2001, "Domestic futures and sustainable residential development", Futures, 33(10):817-836.

Clark, D., Southern, R., Beer, J., 2007, "Rural governance, community empowerment and the new institutionalism: A case study of the Isle of Wight", Journal of Rural Studies, 23(2):254-266.

Costantini, V., Monni, S., 2008, "Environment, human development and economic growth", Ecological Economics, 64(4.1):867-880.

Drakakis-Smith, D., 1981, Urbanisation, housing and the development process, Croom Helm, London. Fetterman, D., 2007, "Empowerment evaluation: Yesterday, today and tomorrow", American Journal of Evolution, 28:179-198.

Fogel, R., 1994, "Economic growth, population theory and physiology: The bearing of long-term processes on the making of public policy”, American Economic Review, June, 369-395.

Forster-Kraus, S., Reed R, Wilkinson, S., 2009, “Affordable Housing in the Context of Social Sustainability”, ISA International Housing Conference, UK.

Gaye, M., Diallo, F., 1997, "Community participation in the management of the urban environment in Rufisque, Senegal", Urban Environment, 9:9-30.

Ghafur, S., 2000, "Entitlement to patronage: Social construction of household claims on Slum Improvement Project, Bangladesh", Habitat International, 24(3):261-278.

Greider, W., 1997, One world, ready or not: The manic logic of global capitalism, Simon, New York. Gutberlet, J., 2009, "Solidarity economy and recycling co-ops: Micro-credit to alleviate poverty", Development Practice, 19:737-751.

Halder, A., Dutt, A., Shi, Q., 2016, "Socioeconomic Characteristics of Calcutta Slums: An Analysis of Intervention Policies", Costa, J., et al. (eds.), Springer, 451-474.

Huby, M., 1998, Social Policy and the Environment, Open University Press, Buckingham.

Huchzermeyer, M., 1999, "The exploration of appropriate informal settlement intervention in South Africa: contributions from a comparison with Brazil”, Ph.D. thesis, University of Cape Town.

IDSS, BCL, Prashika, 1996, "Report of the Urban Poverty Reduction Project", ADB-GOB-LGED, Dhaka. Islam, N., Shafi, S., 2008, "Proposal for a Comprehensive Housing Development Program for the Dhaka City", Nagar Unnayan Committee, Dhaka.

Jepson, E., 2007, "Sustainability and the childe thesis: What are the effects of local characteristics and conditions on sustainable development policy?", Cities, 26:434-444.

Kates, R., Thomas, P., Leiserowitz, A., 2005, "What is sustainable development? Goals, indicators, values, and practice", Environment, 47:9-21. 
Kimm, P., 1987, "Housing Progress in Developing Countries”, Proceedings of the Second International Shelter Conference and Vienna Recommendations on Shelter and Urban Development, Washington DC.

Lall, S., 2006, “A poverty profile for Dhaka, in Dhaka: improving living conditions for the urban poor”, The World Bank, Dhaka.

Laverack, G., 2006, “Using a 'domains' approach to build community empowerment”, Journal of Community Development, Vol 41:4-12.

Le Blanc, D, Buckley, R., 2006, "Employment and poverty in Dhaka: improving living conditions for the urban poor", The World Bank, Dhaka.

Lüthi, C., 2016, "Slum Improvement Lessons in Africa: Kibera”, Geo Journal Library, Vol 119:115-124.

Mac Laren, V., 1996, “Urban sustainability reporting”, Journal of American Planning Association, Vol 62: 184-201

Mansuri, G., Rao V., 2003, "Evaluating Community-Based and Community-Driven Development: A Critical Review of the Evidence", Development Research Group, World Bank, Washington, DC.

Menon, B., 1998, “Informal Settlement Upgrading in Dhaka: Sector Study, Urban Housing and Informal Settlements in Bangladesh: A Background", World Bank: Washington DC.

Moore, N., Soott, M., (eds), 2005, Renewing urban communities environment, Citizenship and sustainability in Ireland, Ashgate, Aldershot.

Narayan, D., Shah T., 2000, Connecting the local to the global: Voices of the poo, World Bank, Washington DC. Nelson, G., Prilleltensky, I., 2005, Community psychology: In pursuit of liberation and well-being, Palgrave Macmillan, New York.

Parris, T., Kates, R., 2003, “Characterizing and measuring sustainable development”, Annual Review of Environment and Resources, Vol 28:559-586.

Patrick, W., Scott, F., 2011, "Decentralization in Developing Countries", Encyclopedia of Public Administration and Public Policy, $2^{\text {nd }}$ edn., Taylor and Francis, London, 498-503.

Peattie, L., 1987, "Shelter development and the poor", in Rodwin L., (ed), Shelter, Settlement and Development, Allen and Unwin, Boston, 263-280.

Pugh, C., 1997, "Poverty and progress? Reflections on housing and urban policies in developing countries, 1976-96", Urban Studies, 34 10: 1547-1596.

Pugh, C., 2000, "Squatter Settlements: their sustainability, architectural contributions and socio-economic roles", Cities, 17(5): $325-337$

Rahman, M., 1999, "Role of the NGOs in urban housing for the poor", McNamara Fellowship Report, World Bank, Washington DC.

Rahman, M., 2001, “Bastee Eviction and Housing Rights- a case of Dhaka, Bangladesh”, Habitat International, Vol 25: 49-67.

Rahman, M., 2010, “Government and housing for the poor: policy and implementation in Bangladesh”, East West Journal of Humanitie, Vol 1(1):147-170.

Rashid, S., Hussain, Y., 2006, “The challenges of service delivery for Dhaka's poor" in Dhaka Improving Living Conditions for the Urban Poor, World Bank, Dhaka

Rondinelli, D., 2006, "Decentralization and Development”, in Haque, A., Zafarullah, H., (eds.) International Development Governance, Taylor and Francis, London.

Roseland, M., 2000, "Sustainable Community Development: integrating environmental, economic and social objectives", Progress in Planning, Vol 54(2): 73-132.

Rovai, A., 2002, "Sense of community, perceived cognitive learning, and persistence in asynchronous learning networks", The Internet and Higher Education, Vol 5(4):319-332.

Saegaert, S., 2006, "Building civic capacity in urban neighborhoods: an empirically grounded anatomy", Journal of Urban Affairs, 28: 275-294. 
Sara and Katz, 1997, "Making rural water sustainable: Report on the impact of project rules", UNDP and World Bank, Washington DC.

Sidorenko, A., 2006, "Empowerment and participation in policy action on ageing", UN Program on Ageing. Paper presented at the international Design for All Conference, Rovaniemi, Finland.

Silvius, G., 2012, "Change the Game: Sustainability in Project and Project Management" in Brocke, J., Seidel, S., Rocker, J., (eds) Green Business Project Management, Springer-Verlag, Berlin, 161-177.

Smets, P., 1999, "Housing finance trapped in a dilemma of perceptions: affordability criteria for the urban poor in India question", Housing Studies, 14:821-838.

SODEV, 1999, "Report on the Evaluation of the Slum Improvement Project", UNICEF-LGED, Dhaka.

Stead, W., Stead, J., 1996, Management for a small planet: Strategic decision making and the environment, Sage, California.

Streatfield, Karar, Z., 2008, "Population Challenges for Bangladesh in the Coming Decades", Journal of Health Population Nutrition, 26(3): 261-272.

Tipple, G., 1994, "A matter of interface: the need for a shift in targeting housing intervention", Habitat International, 18(4):1-15.

Tosics, I., 2004, "European Urban Development: sustainability and the role of housing", Journal of Housing and Built Environment, 19:67-90.

Turner, J., 1976, Housing by People- towards autonomy in building environments, Marion Boyars, London.

Time World, (TW), 2013. “After Much Heartbreak, Some Good News at Last for Bangladesh”, viewed 22 September 2013, from www.timeworld.com.

United Nations, 2000, “United Nations Millennium Declaration”, UN GA 55/2, New York.

United Nations, 2005, "United Nations Millennium Project, investing in development: a practical plan to achieve the millennium development goals", Earthscan, London.

UNCHS, 2003, "The challenges of slums: global report on human settlements", Earthscan, London. UNCHS, 2005, "United Nations Human Settlements Program, financing urban shelter", Earthscan, London. UNCHS, 2014, “KENSUP projects within UN-Habitat. Nairobi”, viewed 10 September 2015, from http://?www.?rrojasdatabank.?info/?slums/?kenyaslum09kensu?p1.?pdf

UNDP-UNCHS-UDD, 2007, “Local partnership for Urban Poverty Alleviation Project completion report”, UNDP-UNCHSGOB, Dhaka.

Urban Partnership for Poverty Reduction (UPPR), 2015, viewed 10 September 2015 from http://www.upprbd.org/keyresults.aspx.

Watt, S., Higgins, C., Kendrick, A., 2000, "Community participation in development of services: A move towards community empowerment", Community Development Journal, 35(2):120-132.

World Bank, 1993, "Housing: Enabling Markets to Work”, Washington DC.

Zimmerman, M., 2000, "Empowerment theory: psychological, organizational, and community levels of analysis", in Rappaport, J., Seidman, E., (eds.) Handbook of Community Psychology, Plenum Press, New York. 